\title{
Relationship between leadership styles and dimensions of employee organizational commitment: A critical review and discussion of future directions
}

\author{
Imen Keskes \\ Universitat Politècnica de Catalunya (Spain) \\ Imen.keskes@gmail.com
}

Received September, 2013

Accepted December, 2013

\section{Abstract}

Purpose: The aim of this work is the study and the discussion of the relationship between leadership styles and organizational commitment dimensions. Both styles of leadership known as transformational and transactional styles differ in the process by which the leader motivates his subordinates. Organizational commitment defined by its three types (Affective, Normative and Continuance) measures the strength of an individual identification with and involvement in the organization.

Design/methodology/approach: An extensive literature research has been done in order to increase our understanding of leadership and organizational commitment as well as the relationship between these two concepts.

Findings: The present study of the relationships between leadership styles and organizational commitment has shown how leadership dimensions can influence employee organizational commitment. Although there is considerable research available suggesting that transformational leadership is positively associated with organizational commitment in a variety of organizational settings and cultures, there has been little empirical research focusing on the precise ways in which style of leadership impacts employee organizational commitment.

Originality/value: Some critics about previous empirical and theoretical studies will 
present and a number of areas for future research will highlight. In this sense, various areas that require additional research are developed and possible incorporation of some mediation variables are proposed in order to gather a better understanding about the mechanism that links leadership styles and followers organizational commitment.

Keywords: Leadership styles, organizational commitment, relationship, literature review, future directions

Jel Codes: M12, M14

\section{Introduction}

Leadership has been always a crucial issue since organizations and companies are permanently in a constant struggle to be increasingly competitive. Leadership is an important function of management which helps to maximize efficiency and to achieve organizational goals. The word leadership has been described in terms of the position, personality, responsibility, influence process; instrument to achieve a goal, behaviors (Limsila \& Ogunlana, 2007). Most definitions have a common theme of directing a group towards a goal. Therefore, the leadership can be broadly defined as the relationship between an individual and a group built around some common interest wherein the group behaves in a manner directed or determined by the leader (Shastri, Shashi Mishra \& Sinha, 2010). Leaders can influence the behavior of their followers through the use of different styles, or approaches, to managing others. For the past three decades, a pair of predominant leadership styles (transactional and transformational leadership) has received a significant amount of attention.

On the other hand, employee commitment has long been a topic of interest to organizational researchers (Meyer, Allen \& Smith, 1993; Meyer \& Allen, 1991, 1984; Mathieu \& Zajac, 1990; Mowday, Porter \& Steers, 1982). One of the main reasons for its popularity is that organisations have continued to find and sustain competitive advantage through teams of committed employees. Many researchers found that an organization's success is determined, in part, by having a high degree of organizational commitment (Jassawalla \& Sashittal, 2003; Brooks, 2002; McElroy, 2001). Organizational commitment has attracted considerable attention in theory and research because of its attempt to understand and clarify the intensity and stability of employee dedication to work organizations (Eisenberger, Fasolo \& Davis-Lamastro, 1990). Research literature states that organizational commitment is defined as a subordinate's identification with the mission, goals, and vision of the organization. According to Eisenberg, Monge and Miller (1983), organizational commitment has been defined in a variety of ways. Most theorists, however, include one or more of the following three attitudinal elements as an integral part of their definition: 
- a strong belief in and acceptance of the organizations goals and values;

- a willingness to exert considerable effort on behalf of the organization, and

- a strong desire to maintain membership in the organization. Generally, higher or lower levels of commitment have been shown to be a major driver of employees staying with or leaving an organization (Shaw, Delery, Jenkins \& Gupta, 1998).

Employee commitment reflects the quality of the leadership in an organization (Stum, 1999). Organizational commitment provides a broad measure of the effectiveness of leadership which offers a way to further explore the subject of the relationship between leadership and commitment. However, organizations are always looking for the committed human resources in order to achieve its strategic objectives. Specifically, supervisors have the responsibility to emphasize to their subordinates their link and contribution to the success of the organization and to understand the significance of building a positive relationship with their respective subordinates to enhancing the subordinate's commitment to the organization (Truckenbrodt, 2000).

In the present paper, an extensive bibliographic research about leadership and organizational commitment has been done. The main objective is to study and discuss the relationship between leadership styles and dimensions of organizational commitment. This study has allowed to highlight and propose some areas for future research.

\section{Styles of leadership}

The leadership literature considers two styles of leadership: transformational and transactional. To motivate employees, the transactional leader uses tangible rewards (e.g., money and status) while the transformational uses intangible rewards (e.g., personal growth, self-esteem, and professional values). Burns (1978) first introduced the concepts of transformational and transactional leadership in his treatment of political leadership, but this term is now used in organizational psychology as well. Bass (1985) extended the work of Burns (1978) by explaining the psychological mechanisms that underlie transformational and transactional leadership. 


\subsection{Transformational leadership}

Transformational leadership has been considered as the most prominent topic in the research and theories of leadership (Bass, 1998; Pawar \& Eastman, 1997). Burns (1978) defined transformational leadership as the process of pursuing collective goals through the mutual tapping of leaders' and followers' motive bases toward the achievement of the intended change. Transformational leadership can be seen when "leaders and followers make each other to advance to a higher level of moral and motivation" (Burns, 1978). Bass (1985) built on Burns (1978) work and described transformational leadership as a style of leadership that transforms followers to rise above their self-interest by altering their morale, ideals, interests, and values, motivating them to perform better than initially expected. Bass (1990b) asserted that transformational leadership "occurs when leaders broaden and elevate the interests of their employees, when they generate awareness and acceptance of the purposes and mission of the group, and when they stir their employees to look beyond their own self-interest for the good of the group" (Bass, 1990b, pp. 21).

Bass (1985) depicted transformational leadership as comprising four distinct factors: charisma, inspiration, individualized consideration and intellectual stimulation. Charisma is shown by leaders who act as role models, create a sense of identification with a shared vision, and instill pride and faith in followers by overcoming obstacles. This dimension is also known as idealized influence and could be further divided into two sub-factors -idealized influence attributed and idealized influence behavior. Inspiration is defined as inspiring and empowering followers to enthusiastically accept and pursue challenging goals and a mission. Individualized consideration consists of behaviors such as communicating personal respect to followers by giving them specialized attention, by treating each one individually, and by recognizing each one's unique needs. Finally, leaders who consider old problems in new ways, articulate these new ideas, and encourage followers to rethink their conventional practice and ideas are said to be intellectually stimulating.

Later, Rafferty and Griffin (2004) re-examine the theoretical model developed by Bass (1985) to identify five dimensions of transformational leadership: vision, inspirational communication, supportive leadership, intellectual stimulation and personal recognition.

- Vision is one of the five elements that contribute to charisma (Weber, 1968). As opposed to the broader construct of charisma or idealized influence proposed by Bass and his colleagues, vision is the expression of an idealized picture of the future based around organizational values. Vision results in the internalization of organizational values and goals that encourages individuals to adopt desired behaviors (McClelland, 1975). House (1977) defined vision as a transcendent ideal that represents shared 
values and argued that charismatic leaders demonstrate a number of behaviors, including articulating an ideology that enhances goal clarity, task focus, and value congruence.

- Inspirational communication is the expression of positive and encouraging messages about the organization and statements that build motivation and confidence. Inspiration refers to "the extent to which a leader stimulates enthusiasm among subordinates for the work of the group and says things to build subordinate confidence in their ability to perform assignments successfully and attain group objectives" (Yukl, 1981, pp. 121). Inspirational leaders use appeals and emotion laden statements to arouse followers' emotions and motivation.

- Supportive leadership is a component of individualized consideration leadership construct. Individualized consideration occurs when a leader has a developmental orientation towards staff and displays individualized attention to followers and responds appropriately to their personal needs (Bass, 1985). As opposed to broader construct of individualized consideration, supportive leadership means expressing concern for followers and taking account of their individual needs. Supportive leaders direct their behavior toward the satisfaction of subordinates' needs and preferences, display concern for subordinates' welfare, and create a friendly and psychologically supportive work environment (House, 1996).

- Intellectual stimulation is enhancing employees' interest in and awareness of problems and increasing their ability to think about problems in new ways (Bass, 1985). Intellectual stimulation increases followers' abilities to conceptualize, comprehend, and analyze problems and improve quality of solutions (Bass \& Avolio, 1990).

- Personal recognition is the provision of rewards such as praise and acknowledgement of effort for achievement of specified goals. Personal recognition occurs when a leader indicates that he or she values individuals' efforts and rewards the achievement of outcomes consistent with the vision through praise and acknowledgment of followers' efforts.

\subsection{Transactional leadership}

Transactional leadership is the second style identified in the literature. Transactional leadership (Bass, 1985; Burns, 1978) refers to a dynamic exchange between leaders and their subordinates, in which the leader establishes specific goals, monitors progress, and identifies 
rewards that can be expected upon goal achievement. It involves an exchange process between the leader and the followers, intended to increase followers' compliance to the leader and to the organizational rules (Yukl, 1998). Bass (1985) characterized the transactional leader as one who operates within the existing system or culture, has a preference for risk avoidance, pays attention to time constraints and efficiency, and generally prefers process over substance as a means for maintaining control. Bass model of leadership (1990a) includes three dimensions: contingent reward, management-by-exception, and laissez-faire, or nonleadership behavior.

- Contingent reward relates back to earlier work conducted by Burns (1978) where the leader assigns work and then rewards the follower for carrying out the assignment. Leaders transact with followers by rewarding effort contractually, telling them what to do to gain rewards, punishing undesired action, and giving extra feedback and promotions for good work (Bass, 1985). Bass (1985) emphasized that by providing contingent rewards, a transactional leader might inspire a reasonable degree of involvement, loyalty, commitment and performance from subordinates.

- Management-by exception (MBE): In general, is the degree to which the leader takes corrective action on the basis of results of leader-follower transactions (Judge \& Piccolo, 2004). Is when the leader monitors the follower, and then corrects him/her if necessary. Leaders transact with followers by intervening only when followers deviate from expectations, giving negative feedback for failure to meet standards. Based on the timing of the leader's interventions a distinction is often made between active and passive management-by-exception (Bass \& Avolio, 1993; Hater \& Bass, 1988). MBE-P includes waiting passively for errors to occur and then taking corrective action. The leader relies heavily on passive management-by-exception, intervenes with his or her group only when procedures and standards for accomplishing tasks are not being met (Bass, 1990a). MBE-A may be necessary when safety is an issue. The leader watches and searches for deviations from rules and standards, takes corrective action (Bass, 1990a). In the more active form of management-by-exception leaders try to anticipate mistakes or problems.

- Laissez-faire leadership is a contrast to the active leadership styles of transformational and transactional leadership. It is virtually an avoidance of leadership behaviors, when an individual avoids making decisions and demonstrates a passive indifference to both tasks and followers. Leadership behaviors are ignored and no transactions are carried out. Leaders who score high on laissez-faire leadership avoid making decisions, hesitate in taking action, and are absent when needed (Judge \& Piccolo, 2004). 


\subsection{The relationship between transactional and transformational leadership}

According to Burns (1978), the difference between transformational and transactional leadership is what leaders and followers offer one another. Transactional leadership occurs when one person takes the initiative in making contact with other for the purpose of an exchange of valued things. Both parties acknowledge the power relationships of the other and together they continue to pursue their respective purposes. The people are not bound together by a mutually similar purpose. In contrast, transformational leadership occurs when one or more persons engage with one another and they increase their levels of motivation and morality. The power base, in this instance, mutually supports a common purpose. This latter form of leadership seeks to "raise the level of human conduct and ethical aspiration of both the leader and led, and thus it has a transforming effect on both" (Burns, 1978, pp. 20).

Burns' view is that transformational leadership is more effective than transactional leadership, where the appeal of the latter is to more selfish concerns. An appeal to social values thus encourages people to collaborate, rather than working as individuals (and potentially compete with one another). He also views transformational leadership as an ongoing process rather than the discrete exchanges of the transactional approach. Burns contrasted transactional and transformational leadership, believing that they lie at opposite ends of a continuum (Bass, 1990a; Yukl, 1989). Burns theorized that transforming and transactional leadership were mutually exclusive styles, an individual can display transformational leadership or transactional leadership, but not both.

Other leadership scholars (e.g., Avolio, Bass \& Jung, 1999; Bass, 1999, 1998, 1985; Bycio, Hackett \& Allen, 1995; Bass \& Avolio, 1993; Waldman, Bass \& Yammarino, 1990; Conger \& Kanungo, 1988) hold a different view, arguing that these styles are not competing, but complementary. For example, Conger and Kanungo (1988) suggested that leaders who rely on contingent rewards (a dimension of transactional leadership) and charisma (a dimension of transformational leadership) may be most successful in empowering their subordinates. Avolio et al. (1999) believe, and have empirically supported the contention, that effective leaders engage in both transformational and transactional behaviors. Similarly Bass (1985) argued that transformational leadership enhances or augments the effects of transactional leadership and that all leaders display leadership styles though to different degrees. Leaders are capable of being both transformational and transactional. In this sense, both styles are regarded as integrated by recognizing that both may be linked to the achievement of desired goals and objectives; their primary difference resides in the process by which the leader motivates subordinates and the types of goals set (Hater \& Bass, 1988). Bass (1985) has depicted transactional leadership as being based on material/economic exchange and transformational leadership as being based on social exchange. Bass believes that every leader displays each of 
the aforementioned styles to some extent; he calls this the "Full Range of Leadership Model" (Bass, 1998, pp. 7).

Although some studies suggest that outstanding leaders display both transformational and transactional styles, it seems that transformational leadership can be more effective than transactional leadership in many cases (for a review, see Limsila \& Ogunlana, 2007; Judge \& Piccolo, 2004; K.B. Lowe, Kroeck \& Sivasubramaniam, 1996).

\subsection{Impact of transformational leadership on followers}

After more than 20 years of accumulated research evidence, there is little doubt that transformational leadership behaviour is related to a wide variety of positive individual and organizational outcomes (Bommer, Robert, Rubin \& Baldwin, 2004). However transformational leadership is important since it has a significant influence on the work attitudes and behaviours of followers. Among the principal outcomes of the transformational leadership on follower found in the literature we can mention:

- Follower job satisfaction: Job satisfaction was defined by Locke (1976) as "a pleasure or positive emotional state resulting from the appraisal of one's job or job experience" (Locke, pp. 1297). Transformational leadership is positively associated with follower job satisfaction. In fact, it has been established that job satisfaction is higher among employees whose leaders emphasize consideration, support, and concern for their followers (Rafferty \& Griffin, 2006; Walumbwa \& Lawler, 2003; Allen \& Meyer, 1990).

- Follower job performance: Transformational leadership is positively associated with job performance (Bono \& Judge, 2003). Walumbwa and his colleagues (Walumbwa, Avolio \& Zhu, 2008) found that supervisor-rated task performance was higher when leaders demonstrate transformational leadership behaviours more frequently as evaluated by their respective followers. However, transformational leadership theory suggests that transformational leadership is related not only to individual follower performance but also to performance at the group and organization levels. DeGroot, Kiker and Cross (2000) suggest that charismatic leadership is more effective at increasing group performance than at increasing individual performance.

- Follower creativity: Preliminary field studies have found significant relationships between transformational leadership and subordinate creativity in Korean research and development departments (Shin \& Zhou, 2007, 2003). P. Wang and Rode's results from multi-level linear modeling analyses indicated that transformational leadership is not 
directly related with employee creativity. However the three-way interaction between transformational leadership, employee identification with leader and innovative climate is associated with employee creativity (P. Wang \& Rode, 2010).

- Follower Organizational citizenship behavior: Charismatic leadership has been conceptually and empirically linked to organizational citizenship behavior (Deluga, 1995; Koh, Steers \& Terborg, 1995). Charismatic leaders are thought to appeal to followers' higher order needs, foster follower dedication to organizational goals, and increase follower self-confidence and self-expectations. These behaviors cause followers to, "do more than they are expected to do" (Yukl, 1989), "perform above and beyond the call of duty" (Bass, 1985), take on greater responsibility, perform beyond expectations, and assume leadership roles themselves (Bass \& Avolio, 1994).The individualized consideration (dimension of transformational leadership) was studied as a possible antecedent of change-oriented and altruist organizational citizenship behaviors (López-Domínguez \& Enache, 2009).

- Follower organizational commitment: There is considerable available research suggesting that transformational leadership is positively associated with organizational commitment in a variety of organizational settings and cultures (Walumbwa, Orwa, Wang \& Lawler, 2005; Avolio, Zhu, Koh \& Bhatia, 2004; Bono \& Judge, 2003; Walumbwa \& Lawler, 2003; Dumdum, Lowe \& Avolio, 2002). However, prior research suggests that organizational commitment was higher for employees whose leaders encouraged participation in decision-making (Jermier \& Berkes, 1979; Rhodes \& Steers, 1981), emphasized consideration (Bycio et al., 1995), and were supportive and concerned for their followers' development (Allen \& Meyer, 1996, 1990).

\section{Organizational Commitment}

Commitment is a force that binds an individual to a course of action that is of relevance to a particular target (Meyer \& Herscovitch, 2001). Although various definitions have emerged in the literature, the most common approach has defined organizational commitment as "the strength of an individual's identification with and involvement in a particular organization" (Porter, Steers, Mowday \& Boulian, 1974, pp. 604). Organizational commitment has an important place in the study of organizational behaviour. This is partly due to the large number of works that have found relationships between organizational commitment and attitudes and behaviours in the workplace. Batemen and Strasser (1984) state that the reasons for studying organizational commitment are related to: 
- "employee behaviours and performance effectiveness,

- attitudinal, affective, and cognitive constructs such as job satisfaction,

- characteristics of the employee's job and role, such as responsibility and

- personal characteristics of the employee such as age, job tenure" (Batemen \& Strasser, 1984, pp. 95-96).

\subsection{Components of organizational commitment}

Meyer and Allen (1991) and Allen and Meyer (1990) identified three separable components reflecting:

- a desire (affective commitment),

- a need (continuance commitment), and

- an obligation (normative commitment) to maintain employment in an organization.

The three-component model developed by Meyer and Allen has been subjected to the greatest empirical scrutiny and has arguably received the greatest support (For a review, see Meyer, Stanley, Herscovitch \& Topolnytsky, 2002 and Meyer \& Allen, 1997). Meyer and Allen (1991) argued that one of the most important reasons for distinguishing among the different forms of organizational commitment was that they have very different implications for behaviour. Although all three forms tend to bind employees to the organization, and therefore relate negatively to turnover, their relations with other types of work behaviour can be quite different (Meyer et al., 2002).

- Affective commitment (AC) entails an acceptance and internalization of the other party's goals and values, a willingness to exert effort on their behalf and a strong emotional attachment to them (Allen \& Meyer, 1990; Mowday, Steers \& Porter, 1979). Employees who are affectively committed to the organisation will probably carry on working for it because they want to (Meyer \& Allen, 1991).

- Normative commitment (NC) entails perceived obligations to maintain employment memberships and relationships. In exchange for employment, employees feel compelled to reciprocate with loyalty and commitment that derive from morality and value-driven principles based on reciprocity norms and socialization practices (Meyer $\&$ 
Herscovitch, 2001). "Employees with a high level of normative commitment feel that they ought to remain with the organization" (Meyer \& Allen, 1991, pp. 67).

- Continuance commitment (CC) involves appraisals of personal investments tied to one's current employment and the availability of employment alternatives (Meyer \& Allen, 1984). Continuance commitment "refers to the awareness of the costs associated with leaving the organization" (Meyer \& Allen, 1991, pp. 67). Individuals with high continuance commitment remain with their organizations because they perceive the costs of leaving to be too great. This type of commitment indicates that employees remain because they have too much time invested (Meyer \& Allen, 1991).

Becker (1960) originally proposed that people engage in consistent lines of behaviour because of the inducements (side bets) to do so. Employers offer a variety of such inducements to retain employees, including job status, seniority and benefits. Further, employees often desire to avoid the social and economic costs of leaving (e.g., relocation costs, disrupted social networks). CC strengthens as these side bets accumulate, rendering employees more likely to stay with the organization. Meyer and Allen (1991) also indicate that individuals whose most important connection to the organisation is based on continuance commitment stay because they need to.

It has been recognized two sub-dimensions of continuance commitment held in various empirical studies (Vandenberghe, Michon, Tremblay, Bentein, Chebat \& Fils, 2007; Bentein, Vandenberg, Vandenberghe \& Stinglhamber, 2005; Powell \& Meyer, 2004; Meyer, Allen \& Gellatly, 1990; McGee \& Ford, 1987).

- Commitment due to a lack of alternative employment opportunities (CC: LoAlt) reflected commitment based on few existing employment alternatives. This commitment refrains the individual from leaving the organization, due to the perceived lack of more desirable employment opportunities.

- Perceived sacrifice of investments associated with leaving the organization CC: HiSac) related to fear of losing benefits acquired by the organization during the years of work. This commitment is driven by the perception of loosing the investments done in the targeted organized if it is abandoned by the individual. 


\subsection{Outcomes of organizational commitment}

The interest of researchers in the construct of organizational commitment can be understood in relation to its links with desirable work outcomes. There seems to be a consensus that employees' organizational commitment influences their work attitudes and behaviors. Several decades of research demonstrate that organizational commitment can have positive consequences for the organization and the individual employee (O'Driscoll, Pierce \& Coghlan, 2006; Riketta \& van Dick., 2005; Meyer et al., 2002; Mathieu \& Zajac, 1990).

Organizational commitment is important for organizational effectiveness in that it enhances employees' desire to remain in an organization, improves their performance (Porter et al., 1974), and stimulates their utmost efforts to accomplish the organization's goals (Schaubroeck \& Ganster, 1991; Meyer, Paunonen, Gellatly, Goffin \& Jackson, 1989). It is also related to numerous work-related attitudes and behaviors, including satisfaction, involvement with one's job and work motivation (Markovits, Davis \& Vandick, 2007; Chughtai \& Zafar, 2006; CooperHakim \& Viswesvaran, 2005; Meyer et al., 2002; Allen \& Meyer, 1996; Mowday et al., 1982). Moreover, organizational commitment has been linked to increased knowledge sharing (Alvesson, 2001), increased organizational citizenship behaviours (Meyer et al., 2002; Riketta, 2002), better organizational performance (Ricketta, 2002; Meyer et al., 1989), reduced absenteeism (Eby, Freeman, Rush \& Lance, 1999) and reduced turnover (Chughtai \& Zafar, 2006; Cooper-Hakim \& Viswesvaran, 2005; Mathieu \& Zajac, 1990). Employee turnover is very costly as organizations have to spend money on exit interviews, severance pay, hiring costs, and lost productivity while training the new hires. Bergmann, Lester, De Meuse and Grahn (2000) conclude that getting the best workers and keeping them committed to the organization can help organizations survive and also increase their competitiveness.

\section{Leadership styles and organizational commitment}

Prior research suggests that work experiences, personal and organizational factors serve as antecedents to organizational commitment (Eby et al., 1999; Meyer \& Allen, 1997; Allen \& Meyer, 1996, 1990). One organizational factor that is considered a key determinant of organizational commitment is leadership (Mowday et al., 1982).

Lee (2004) found out that transformational leadership correlates significantly with organizational commitment with samples of research and development professional in Singapore. Contrary, transactional leadership does not have significant relationship with organizational commitment. Hayward, Goss and Tolmay (2004) findings have further indicated that no correlation was found between transactional leadership and affective, normative and 
continuance commitment. Limsila and Ogunlana (2007) found that the leadership style mostly adopted and proving to be most suitable for Thai people is the transformational leadership. In addition, their result reveals that transformational leadership style is likely to generate commitment from subordinates while transactional and laissez-faire are not.

The links between transformational leadership and organizational commitment are well established (Walumbwa et al., 2005; Avolio et al., 2004; Walumbwa \& Lawler, 2003; Dvir, Eden, Avolio \& Shamir, 2002; Howell \& Hall-Merenda, 1999; Kirkpatrick \& Locke, 1996). Essentially, the empirical and meta-analytic studies suggest that followers working with transformational leaders are more committed to their organizations and demonstrate fewer withdrawal behaviors (Walumbwa, Wang, Lawler \& Shi, 2004; Bono \& Judge, 2003; Walumbwa \& Lawler, 2003; Barling, Weber \& Kelloway, 1996). Transformational leaders have great ability to influence organizational commitment by promoting the values which are related to the goal accomplishment, by emphasizing the relation between the employees efforts and goal achievement and by creating a greater degree of personal commitment on part of both follower's as well as leaders for the achievement of ultimate common vision, mission and goals of the organization (Shamir, Zakay \& Popper, 1998). Transformational leaders influence followers' organizational commitment by encouraging followers to think critically by using novel approaches, involving followers in decision-making processes, inspiring loyalty, while recognizing and appreciating the different needs of each follower to develop his or her personal potential (Avolio, 1999; Bass \& Avolio, 1994; Yammarino, Spangler \& Bass, 1993). This is further supported by Walumbwa and Lawler (2003) that transformational leaders can motivate and increase followers' motivation and organizational commitment by getting them to solve problems creatively and also understanding their needs.

Transformational leadership behaviour may encourage employees in both regular and irregular ways to develop stronger employee commitment (Bass, 1985). Although transformational leadership has been conceptually and empirically linked to organizational commitment, there has been little empirical research focusing on the precise ways in which style of leadership impacts employee organizational commitment.

\section{Discussion}

A multitude of studies have substantiated empirical results about leadership styles and the dimensions of organizational commitment. Hayward et al. (2004) noted that transformational leadership has moderate positive correlation with affective commitment. Low correlation coefficients between transformational leadership and normative and continuance commitment 
were also found. Other researchers such as Kent and Chelladurai (2001) posited that individualized consideration has positive relationship with both affective commitment and normative commitment. Similarly, positive correlations was found between intellectual stimulation and both affective commitment and normative commitment. Contrary to their hypotheses, Simosi and Xenikou (2010) found that transformational leadership did not explain how continuance commitment develops. Only the subscale of personal sacrifices was linked to transactional contingent reward.

Rafferty and Griffin (2004) found conflicting empirical results en relation with continuance commitment. They hypothesized that personal recognition has a unique positive relationship with CC. Contrary to their expectations; personal recognition was significantly negatively associated with CC. Moreover, they found that vision displayed a unique negative association with CC (not hypothesized in their work). These results may be explained by focusing on the composition of the CC scale, which contains items measuring individuals' perceptions of their investments in the organization and the availability of alternative employment possibilities. When the only rewards that are available for use by leaders are verbal encouragement or rewards of a personal nature, this may result in follower frustration as people do not feel that they are being adequately rewarded for performance. Increased frustration may lead individuals to evaluate alternative opportunities more positively, reducing $\mathrm{CC}$ to the organization (Rafferty \& Griffin, 2004). Regarding the relationship between vision and CC, alternate expectations were consequently proposed: on the one hand, vision can be positively associated with continuance commitment as articulating an idealized picture of the future increases people's investment in the future of an organization. On the other hand, vision may be associated with a decrease in $\mathrm{CC}$ by empowering people and positively influencing their perceptions of the opportunities available to them (Rafferty \& Griffin, 2004).

Most previous studies have been focused on the affective commitment dimension of organizational commitment. While a relationship between transformational leadership and affective organizational commitment has been empirically established (e.g. Castro, Periñan \& Bueno, 2008; Felfe, Yan \& Six, 2008; Metscher, 2005; Walumbwa et al., 2005, 2004; Dvir, Kass \& Shamir, 2004; Bono \& Judge, 2003; Meyer et al., 2002; W.A. Lowe, 2000; Bycio et al., 1995), the relationship between transformational leadership and employees' normative commitment has only been theoretically supported (Simosi \& Xenikou, 2010). This may be explained by the extensive literature on the determinants of affective commitment, while there have been relatively few empirical investigations examining the antecedents of normative and continuance commitment. Despite the difficulties associated with the measurement of their antecedents, it is important to continue to investigate how continuance and normative commitment develop (Meyer et al., 2002). 
Within a transformational leadership framework, the ability of leaders to properly implement transformational processes, such as intellectual stimulation, individualized consideration, individualized influenced attributed and individualized influence behavior in managing organization functions may lead to an increased organizational commitment (Simon, 1994). Although direct effects model based study has provided significant findings, it does not sufficiently explain how and why transformational leadership style affect organizational commitment in dynamic organizations (Avolio et al., 2004; Bycio et al., 1995).

\section{Conclusions}

The aim of this work was to study of the relationship between leadership styles and organizational commitment dimensions. Firstly, the contemporary leadership literature was studied and the two styles: transformational and transactional were detailed. Secondly, our literature study focused on organizational commitment identified with its three components affective commitment, continuance commitment, and normative commitment. The attention was focused then on showing the importance of the leadership behaviours in influencing employee commitment by different ways. Finally, some critics about previous empirical and theoretical studies will present and a number of areas for future research will highlight.

In order to revise and to generalize the results of the previous studies, the relationship between leadership styles and components of organizational commitment should be conducted in various cities, different cultures and at different organizational levels. This study can further be enhanced by considering the three dimensions of organizational commitment while considering the two sub-dimensions of continuance commitment and the dimensions of leadership styles.

There is substantial evidence that transformational leadership is positively related to employee organizational commitment. This was demonstrated in numerous studies which have applied a direct effect approach to examine the effect of transformational leadership on organizational commitment. However, the mechanisms by which transformational leaders influence their followers have not been studied in a systematic manner (Avolio et al., 2004), and several authors have suggested that greater attention should be paid to understand how these influential processes operate in transformational leadership (Kark \& Shamir, 2002; Conger, Kanungo \& Menon, 2000; Bass, 1999; Yukl 1999). Despite the lack of systematic research in this area, the future study will may focus on the possible mediating role of LMX, procedural justice, employee positive mood... 


\section{Limitations and recommendations for future research}

In the majority of reported studies, transformational leadership has been considered as a single construct (Simosi \& Xenikou, 2010; Castro et al., 2008, Walumbwa et al., 2005; Avolio et al., 2004). Defining and testing models that take into account the diverse dimensions of transformational and transactional leadership can allow us to gain a more precise understanding about how leadership enhances employee commitment.

Previous research has found contradictory findings about the relationship between transformational leadership and continuance commitment (Simosi \& Xenikou, 2010; Rafferty \& Griffin, 2004).Taking into account the two subdimensions of continuance commitment can allow us to test how does it relate to transformational leadership, and the relationship between transactional leadership and employee commitment.

One area that clearly requires additional research is the influence of vision on employees. However, as Rafferty and Griffin (2004) mentioned, there is a clear need to more understand the theoretical nature of the relationship between vision and continuance commitment. Taking into account the two subdimensions of continuance commitment can allow us to test how it relate to vision

The literature about the relationship between leadership and commitment has tested direct relationships between these two constructs. However, some studies draw on social exchange theory to define more elaborated models of the relationship between leadership and attitudinal outcomes (Asgari, Silong, Ahmad \& Sama, 2008; Ngodo, 2008; H. Wang, Law, Hackett, Wang \& Chen, 2005; Pillai, Schriesheim \& Williams, 1999). In those models, constructs such as leader-member exchange (LMX), perceived organizational support and organizational justice act as mediating variables. Incorporating these variables in future research can allow us to gather a better understanding about the social of psychological mechanism that link leadership styles and followers organizational commitment.

\section{Acknowledgments}

This work has been financially supported by a grant from the "Agencia Española de Cooperación Internacional para el Desarrollo" (AECID). 


\section{References}

ALLEN, N.J.; MEYER J.P. (1990). The measurement and antecedents of affective, continuance and normative commitment to the organization. Journal of Occupational Psychology, 63: 1-18. http://dx.doi.org/10.1111/j.2044-8325.1990.tb00506.x

ALLEN, N.J.; MEYER J.P. (1996). Affective, continuance and normative commitment to the organization: an examination of construct validity. Journal of Vocational Behavior, 49: 252-276. http://dx.doi.org/10.1006/jvbe.1996.0043

ALVESSON, M. (2001). Knowledge work: Ambiguity, image and identity. Human Relations, 54(7): 863-886. http://dx.doi.org/10.1177/0018726701547004

ASGARI, A.; SILONG, A.D.; AHMAD, A.; SAMA, B.A. (2008). The relationship between transformational leadership behaviors, leader-member exchange and organizational citizenship behaviors. European Journal of Social Sciences, 6(4): 140-151.

AVOLIO, B.J. (1999). Full leadership development. Thousand Oaks, CA: Sage.

AVOLIO, B.J.; BASS, B.M.; JUNG, D.I. (1999). Reexamining the components of transformational and transactional leadership using the Multifactor Leadership Questionnaire. Journal of Occupational and Organizational Psychology, 72: 441-462. http://dx.doi.org/10.1348/096317999166789

AVOLIO, B.J.; ZHU, W.; KOH, W.; BHATIA, P. (2004). Transformational leadership and organizational commitment: mediating role of psychological empowerment and moderating role of structural distance. Journal of Organizational Behavior, 25: 951-968. http://dx.doi.org/10.1002/job.283

BARLING, J.; WEBER, T.; KELLOWAY, E.K. (1996). Effects of Transformational Leadership Training on Attitudinal and Financial Outcomes: A Field Experiments. Journal of Applied Psychology, 81(6): 827-832. http://dx.doi.org/10.1037/0021-9010.81.6.827

BASS, B.M. (1985). Leadership and performance beyond expectations. New York: Free Press.

BASS, B.M. (1990a). Bass and Stogdill's handbook of leadership: Theory, research, and managerial applications (3rd ed.). New York: The Free Press.

BASS, B.M. (1990b). From transactional to transformational leadership: Learning to share the vision. Organizational Dynamics, 18: 19-31. http://dx.doi.org/10.1016/0090-2616(90)90061-S

BASS, B.M. (1998). Transformational leadership: Industry, Military, and Educational Impact. Hillsdale, NJ: Lawrence Erlbaum.

BASS, B.M. (1999). On the taming of charisma: a reply to Janice Beyer. Leadership Quarterly, 10: 541-553. http://dx.doi.org/10.1016/S1048-9843(99)00030-2 
BASS, B.M.; AVOLIO, B.J. (1990). The implications of transactional and transformational leadership for individual, team, organizational development. Research in Organizational Change and Development, 4: 231-272.

BASS, B.M.; AVOLIO, B.J. (1993). Transformational leadership: A response to critiques. In M. M. Chemmers \& R. Ayman (Eds.), Leadership theory and research: Perspectives and directions (pages 49-88).

BASS, B.M.; AVOLIO, B.J. (1994). Improving organizational effectiveness through transformational leadership. Thousand Oaks, CA: Sage.

BATEMEN, T.; STRASSER, S. (1984). A longitudinal analysis of the antecedents of organizational commitment. Academy of Management Journal, 21: 95-112. http://dx.doi.org/10.2307/255959

BECKER, H.S. (1960). Notes on the concept of commitment. American Journal of Sociology, 66: 32-42. http://dx.doi.org/10.1086/222820

BENTEIN, K.; VANDENBERG, R.; VANDENBERGHE, C.; STINGLHAMBER, F. (2005). The role of change in the relationship between commitment and turnover: A latent growth modeling approach. Journal of Applied Psychology, 90(3): 468-482. http://dx.doi.org/10.1037/00219010.90.3.468

BERGMANN, T.J.; LESTER, S.W.; DE MEUSE, K.P.; GRAHN, J.L. (2000). Integrating the three domains of employee commitment: an exploratory study. Journal of Business and Industrial Marketing, 16(4): 15-26.

BOMMER, W.H.; ROBERT, S.; RUBIN, R.S.; BALDWIN, T.T. (2004). Setting the stage for effective leadership: Antecedents of transformational leadership behaviour. The Leadership Quarterly, 15: 195-210. http://dx.doi.org/10.1016/j.leaqua.2004.02.012

BONO, J.E.; JUDGE, T.A. (2003). Self-Concordance at Work: Toward Understanding the Motivational Effects of Transformational leaders. Academy of Management Journal, 46(5): 554-571. http://dx.doi.org/10.2307/30040649

BROOKS, G. (2002). Knowledge-based structures and organizational commitment. Management Decision, 40: 566-573. http://dx.doi.org/10.1108/00251740210433954

BURNS, J.M. (1978). Leadership. New York: Harper and Row.

BYCIO, P.; HACKETT, R.D.; ALLEN, J.S. (1995). Further assessments of Bass's (1985) conceptualization of transformational and transactional leadership. Journal of Applied Psychology, 80: 468-478. http://dx.doi.org/10.1037/0021-9010.80.4.468 
CASTRO, C.B.; PERIÑAN, M.M.V.; BUENO, J.C.C. (2008). Transformational leadership and followers' attitudes: the mediating role of psychological empowerment. The International Journal of Human Resource Management, 19(10): 1842-1863. http://dx.doi.org/10.1080/09585190802324601

CHUGHTAI, A.A.; ZAFAR, S. (2006). Antecedents and Consequences of Organizational Commitment among Pakistani university teachers. Applied H.R.M. Research, 11(1): 39-64.

CONGER, J.A.; KANUNGO, R.N. (1988). The empowerment process: Integrating theory and practice. Academy of Management Review, 13: 471-482.

CONGER, J.A.; KANUNGO, R.N.; MENON, S.T. (2000). Charismatic leadership and follower effects. Journal of Organizational Behavior, 21: 747-767. http://dx.doi.org/10.1002/10991379(200011)21:7<747::AID-JOB46>3.0.CO;2-J

COOPER-HAKIM, A.; VISWESVARAN, C. (2005). The construct of work commitment: Testing an integrative framework. Psychological Bulletin, 131(2): 241-259. http://dx.doi.org/10.1037/00332909.131.2.241

DEGROOT, T.; KIKER, D.S.; CROSS, T.C. (2000). A Meta-Analysis to Review Organizational Outcomes Related to Charismatic Leadership. Canadian Journal of Administrative Sciences, 17(4): 356-372. http://dx.doi.org/10.1111/j.1936-4490.2000.tb00234.x

DELUGA, R.J. (1995). The relationship between attributional charismatic leadership and organizational citizenship behavior. Journal of Applied Social Psychology, 26: 1652-1669. http://dx.doi.org/10.1111/j.1559-1816.1995.tb02638.x

DUMDUM, U.R.; LOWE, K.B.; AVOLIO, B. (2002). A meta-analysis of transformational and transactional leadership correlates of effectiveness and satisfaction: an update and extension. In B.J. Avolio \& F.J. Yammarino (Eds.), Transformational and charismatic leadership: The road ahead (Vol. 2, pages 35-66). Oxford, U.K.: Elsevier Science.

DVIR, T.; EDEN, D.; AVOLIO, B.; SHAMIR, B. (2002). Impact of transformational leadership on follower development and performance: a field experiment. Academy of Management Journal, 45: 735-744. http://dx.doi.org/10.2307/3069307

DVIR, T.; KASS, N.; SHAMIR, B. (2004). The emotional bond: vision and organizational commitment among high-tech employees. Journal of Organizational Change Management, 17(2): 126-143. http://dx.doi.org/10.1108/09534810410530575

EBY, L.T.; FREEMAN, D.M; RUSH, M.C.; LANCE, C.E. (1999). Motivational bases of affective organizational commitment: a partial test of an integrative theoretical model. Journal of Occupational and Organizational Psychology, 72(4): 463-483. http://dx.doi.org/10.1348/096317999166798 
EISENBERG, E.M.; MONGE, P.R.; MILLER, K.I. (1983). Involvement in Communication Networks as a Predictor of Organizational commitment. Human Communication Research, 10(2): 179-201. http://dx.doi.org/10.1111/j.1468-2958.1983.tb00010.x

EISENBERGER, R.; FASOLO, P.; DAVIS-LAMASTRO, V. (1990). Perceived organizational support and employee diligence, commitment and innovation. Journal of Applied Psychology, 75(1): 51-59. http://dx.doi.org/10.1037/0021-9010.75.1.51

FELFE, J.; YAN, W.; SIX, B. (2008). The impact of individual collectivism on commitment and its influence on organizational citizenship behavior and turnover in three countries. International Journal of Cross Cultural Management, 8: 211-237. http://dx.doi.org/10.1177/1470595808091790

HATER, J.J.; BASS, B.M. (1988). Superiors' evaluations and subordinates' perceptions of transformational and transactional leadership. Joumal of Applied Psychology, 73: 695-702. http://dx.doi.org/10.1037/0021-9010.73.4.695

HAYWARD, Q.; GOSS, M.; TOLMAY, R. (2004). The relationship between transformational and transactional leadership and employee commitment. Grahamstown: Rhodes University, Business Report.

HOUSE, R.J. (1977). A 1976 theory of charismatic leadership. In J. G. Hunt, and L. L. Lawson (Eds.), Leadership: The cutting edge (pages 189-207). Carbondale: Southern Illinois University Press.

HOUSE, R.J. (1996). Path - goal theory of leadership: Lessons, legacy, a reformulated theory. The Leadership Quarterly, 7(3): 323-353. http://dx.doi.org/10.1016/S1048-9843(96)90024-7

HOWELL, J.M.; HALL-MERENDA, K.E. (1999). The ties that bind: The impact of leader-member exchange, transformational and transactional leadership and distance on predicting follower performance. Journal of Applied Psychology, 84(5): 680-694. http://dx.doi.org/10.1037/00219010.84 .5 .680

JASSAWALLA, A.R.; SASHITTAL, H.C. (2003). Building collaborative new product processes: Why instituting teams are not enough. Advanced Management Journal, 68(1): 27-30.

JERMIER, J.M.; BERKES, L.J. (1979). Leader behavior in a police command bureaucracy: a closer look at the quasi-military model. Administrative Science Quarterly, 24: 1-23. http://dx.doi.org/10.2307/2989873

JUDGE, T.A.; PICCOLO, R.F. (2004). Transformational and transactional leadership: a Metaanalytic test of their relative validity. Journal of Applied Psychology, 89(5): 755-768. http://dx.doi.org/10.1037/0021-9010.89.5.755 
KARK, R.; SHAMIR, B. (2002). The dual effect of transformational leadership: Priming relational and collective selves and further effects on followers. In B.J. Avolio \& F.J. Yammarino (Eds.), Transformational and Charismatic Leadership: The Road Ahead (Vol. 2, pages 67-91). Amsterdam: JAI Press.

KENT, A.; CHELlADURAI, P. (2001). Perceived transformational leadership, organizational commitment and citizenship behavior: A case study in intercollegiate athletics. Journal of Sport Management, 15(2): 135-159.

KIRKPATRICK, S.A.; LOCKE, E.A. (1996). Direct and indirect effects of three core characteristic components on performance and attitudes. Journal of Applied Psychology, 81: 36-51. http://dx.doi.org/10.1037/0021-9010.81.1.36

KOH, W.L.; STEERS, R.M.; TERBORG, J.R. (1995). The effects of charismatic leadership on teacher attitudes and student performance in Singapore. Journal of Organizational Behavior, 16: 319-333. http://dx.doi.org/10.1002/job.4030160404

LEE, J. (2004). Effects of leadership and leader-member exchange on commitment. Leadership and Organization Development Journal, 26: 655-672. http://dx.doi.org/10.1108/01437730510633728

LIMSILA, K.; OGUNLANA, S.O. (2007). Performance and leadership outcome correlates of leadership styles and subordinate commitment. Engineering, Construction and Architectural Management, 15(2): 164-184. http://dx.doi.org/10.1108/09699980810852682

LOCKE, E.A. (1976). The Nature and Causes of Job Satisfaction. Handbook of Industrial and Organizational Psychology, Chicago: Rand McNally, 1297-1350.

LÓPEZ-DOMÍNGUEZ, M.; ENACHE, M. (2009). Consideración individualizada, clima organizativo innovador y personalidad proactiva como antecedentes de los comportamientos de ciudadanía organizativa orientados al cambio y altruistas. Intangible Capital, 5(4): 418-438.

LOWE, K.B.; KROECK, K.G.; SIVASUBRAMANIAM, N. (1996). Effectiveness correlates of transformational and transactional leadership: A meta-analytic review of the MLQ literature. Leadership Quarterly, 7: 385-425. http://dx.doi.org/10.1016/S1048-9843(96)90027-2

LOWE, W.A. (2000). An examination of the relationship between leadership practices and organizational commitment in the fire service. Unpublished Dissertation, Nova Southeastern University.

MARKOVITS, Y.; DAVIS, A.J.; VANDICK, R. (2007). Organizational commitment profiles and job Satisfaction among Greek private and public sector employees. International Journal of Cross Cultural Management, 7(1): 77-99. http://dx.doi.org/10.1177/1470595807075180 
MATHIEU J.; ZAJAC, D. (1990). A review of meta-analysis of the antecedents, correlates and consequences of organizational commitment. Psychological Bulletin, 108(2): 171-194. http://dx.doi.org/10.1037/0033-2909.108.2.171

MCCLELLAND, D.C. (1975). Power: The inner experience. New York: Irvington Publishers.

MCELROY, J.C. (2001). Management workplace commitment by putting people first. Human Resource Management Review, 11(3): 327-335. http://dx.doi.org/10.1016/S1053-4822(00)00054-1

MCGEE, G.W.; FORD, R.C. (1987). Two (ore more?) dimensions of organizational commitment: Reexamination of the affective and continuance commitment scales. Journal of applied Psychology, 7: 638-641. http://dx.doi.org/10.1037/0021-9010.72.4.638

METSCHER, D.S. (2005). An examination of the perceived leadership practices and organizational commitment of active duty Air Force personnel and government civil service employees. Unpublishedn Dissertation, Nova Southeastern University.

MEYER, J.P; ALLEN, N.J. (1991). A three-component conceptualization of organizational commitment. Human Resource Management Review, 1(1): 61-89. http://dx.doi.org/10.1016/1053-4822(91)90011-Z

MEYER, J.P; ALLEN, N.J. (1997). Commitment in the workplace: Theory, research and application. Thousand Oaks, CA: Sage.

MEYER, J.P.; ALLEN, N.J. (1984). Testing the 'side-bet theory' of organizational commitment: Some methodological considerations. Journal of Applied Psychology, 6(9): 372-378. http://dx.doi.org/10.1037/0021-9010.69.3.372

MEYER, J.P.; ALLEN, N.J.; GELLATLY, I.R. (1990). Affective and continuance commitment to the organization: Evaluation of measures and analysis of concurrent and time-lagged relations. Journal of Applied Psychology, 75: 710-720. http://dx.doi.org/10.1037/0021-9010.75.6.710

MEYER, J.P.; ALLEN, N.J.; SMITH, C.A. (1993). Commitment to organizations and occupations: Extension and test of a three-component conceptualization. Journal of Applied Psychology, 78: 538-551. http://dx.doi.org/10.1037/0021-9010.78.4.538

MEYER, J.P.; ANDHERCOVITCH, L. (2001).Commitment in the work place: Toward a general model. Human Resource Management Review, 11: 299-326. http://dx.doi.org/10.1016/S10534822(00)00053-X

MEYER， J.P.; PAUNONEN, V.; GELLATLY, I.R.; GOFFIN, R.D.; JACKSON, D.N. (1989). Organizational commitment and job performance: It's the nature of the commitment that counts. Journal of Applied Psychology, 74(1): 152-156. http://dx.doi.org/10.1037/00219010.74.1.152 
MEYER, J.P.; STANLEY, D.J, HERSCOVITCH, L.; TOPOLNYTSKY, L. (2002). Affective, Continuance, and Normative Commitment to the Organization: A Meta-analysis of Antecedents, Correlates, and Consequences. Journal of Vocational Behavior, 61: 20-52. http://dx.doi.org/10.1006/jvbe.2001.1842

MOWDAY, R.T.; PORTER, L.W.; STEERS, R.M. (1982). Employee-organization linkages: The psychology of commitment, absenteeism and turnover. New York: Academic Press. http://dx.doi.org/10.1016/0001-8791(79)90072-1

MOWDAY, R.T.; STEERS, R.M.; PORTER, L.W. (1979). The measurement of organizational commitment. Journal of vocational behaviour, 14: 224-247.

NGODO, O.E. (2008). Procedural Justice and Trust: The Link in the Transformational Leadership - Organizational Outcomes Relationship. International Journal of Leadership Studies, 4(1): 82-100.

O'DRISCOLL, M.P.; PIERCE, J.L.; COGHLAN, A.M. (2006). The psychology of ownership: Work environment structure, organizational structure, and organizational citizenship behaviors. Group and Organization Management, 31: 388-416. http://dx.doi.org/10.1177/1059601104273066

PAWAR, B.S.; EASTMAN, K.K. (1997). The Nature and Implications of Contextual Influences on Transformational leadership: A conceptual Examination. Academy of Management Review, 22: 80-109.

PILLAI, R.; SCHRIESHEIM, C.A.; WILLIAMS, E.S. (1999). Fairness perceptions and trust asmediators for transformational and transactional leadership: A two-sample study. Journal of Management, 25(6): 897-933. http://dx.doi.org/10.1177/014920639902500606

PORTER, L.W.; STEERS, R.M.; MOWDAY, R.T.; BOULIAN, P.V. (I974). Organizational commitment. job satisfaction and turnover among psychiatric technicians. Journal of applied Psvchologv, 59: 603-609.

POWELL, D.M.; MEYER, J.P. (2004). Side-bet theory and the three-component model of organizational commitment. Journal of Vocational Behavior, 65: 157-177. http://dx.doi.org/10.1016/S0001-8791(03)00050-2

RAFFERTY, A.E; GRIFFIN, M.A. (2004). Dimensions of transformational leadership: Conceptual and empirical extensions. The Leadership Quarterly, 15: 329-354. http://dx.doi.org/10.1016/j.leaqua.2004.02.009

RAFFERTY, A.E.; GRIFFIN, M.A. (2006). Refining Individualized Consideration: Distinguishing Developmental Leadership and Supportive Leadership. Journal of Occupational and Organizational Psychology, 79: 37-61. http://dx.doi.org/10.1348/096317905×36731

RHODES, S.R.; STEERS, R.M. (1981). Conventional vs. worker-owned organizations. Human Relations, 12: 1013-1035. http://dx.doi.org/10.1177/001872678103401201 
RIKETTA, M. (2002). Attitudinal organizational commitment and job performance: A metaanalysis. Journal of Organizational Behavior, 23: 257-266. http://dx.doi.org/10.1002/job.141

RIKETTA, M.; VAN DICK, R. (2005). Foci of attachment in organizations: A meta-analytic comparison of the strength and correlates of workgroup versus organizational identification and commitment. Journal of Vocational Behavior, 67(3): 490-510. http://dx.doi.org/10.1016/j.jvb.2004.06.001

SCHAUBROECK, J.; GANSTER, D. (1991). Beyond the call of duty: A field study of extra role behavior in voluntary organization. Human Relations, 44(6): 569-586. http://dx.doi.org/10.1177/001872679104400603

SHAMIR, B.; ZAKAY, E.; POPPER, M. (1998). Correlates of charismatic leader behaviour in military units: subordinates' attitudes, unit characteristics, and superiors' appraisals of leader performance. Academy of management journal, 41(4): 387-409. http://dx.doi.org/10.2307/257080

SHASTRI, R.K.; SHASHI MISHRA, K.; SINHA, A. (2010). Charismatic leadership and organizational commitment: An Indian perspective. African Journal of Business Management, 4(10): 1946-1953.

SHAW, J.; DELERY, J.; JENKINS, G.; GUPTA, N. (1998). An organization-level analysis of voluntary and involuntary turnover. Academy of Management Journal, 41(5): 511-525. http://dx.doi.org/10.2307/256939

SHIN, S.J.; ZHOU, J. (2003). Transformational leadership, conservation and creativity: Evidence from Korea. Academy of Management Journal, 46(6): 703-714. http://dx.doi.org/10.2307/30040662

SHIN, S.J.; ZHOU, J. (2007). When is educational specialization heterogeneity related to creativity in research and development teams? Transformational leadership as a moderator. Journal of applied Psychology, 92(6): 1709-1721. http://dx.doi.org/10.1037/0021-9010.92.6.1709

SIMON, L. (1994). Trust in leadership: Its dimensions and mediating role. Unpublished Dissertation. Manhattan, KS: Kansas State University.

SIMOSI, M.; XENIKOU, A. (2010). The role of organizational culture in the relationship between leadership and organizational commitment: an empirical study in a Greek organization. The International Journal of Human Resource Management, 21(10): 1598-1616. http://dx.doi.org/10.1080/09585192.2010.500485

STUM, D.L. (1999). Workforce Commitment: Strategies for the New Work Order. Strategy and Leadership, 27(1): 4-7. http://dx.doi.org/10.1108/eb054623 
TRUCKENBRODT, Y.B. (2000). The relationship between leader-member exchange and commitment and organizational citizenship Behavior. Acquisition Review Quarterly, Summer: 233-244.

VANDENBERGHE, C.; MICHON, R.; TREMBLAY, M.; BENTEIN, K.; CHEBAT, J.C.; FILS, J.F. (2007). An Examination of the Role of Perceived Support and Employee Commitment in Employee-Customer Encounters. Journal of Applied Psychology, 92(4): 1177-1187. http://dx.doi.org/10.1037/0021-9010.92.4.1177

WALDMAN, D.A.; BASS, B.M.; YAMMARINO, F.J. (1990). Adding to contingent-reward behavior: The augmenting eVects of charismatic leadership. Group and Organization Studies, 15: 381-394. http://dx.doi.org/10.1177/105960119001500404

WALUMBWA, F.O.; AVOLIO, B.J.; ZHU, W. (2008). How Transformational Leadership weaves its influence on individual job performance: The role of identification and efficacy beliefs. Personnel Psychology, 61: 793-825. http://dx.doi.org/10.1111/j.1744-6570.2008.00131.x

WALUMBWA, F.O.; LAWLER, J.J. (2003). Building effective organizations: Transformational leadership, collectivist orientation, work-related attitudes, and withdrawal behaviors in three emerging economies. International Journal of Human Resource Management, 14: 1083-1101. http://dx.doi.org/10.1080/0958519032000114219

WALUMBWA, F.O.; ORWA, B.; WANG, P.; LAWLER, J.J. (2005). Transformational leadership, organizational commitment, and job satisfaction: A comparative study of Kenyan and U.S. financial firms. Human Resource Development Quarterly, 16(2): 235-256. http://dx.doi.org/10.1002/hrdq.1135

WALUMBWA, F.O.; WANG, P.; LAWLER, J.J.; SHI, K. (2004). The role of collective efficacy in the relations between transformational leadership and work outcomes. Journal of Organizational and Occupational Psychology, 77: 515-530. http://dx.doi.org/10.1348/0963179042596441

WANG, H.; LAW, K.S.; HACKETT, R.D.; WANG, D.; CHEN, Z.X. (2005). Leader-member exchange as a mediator of the relationship between transformational leadership and followers' performance and organizational citizenship behavior. Academy of Management Journal, 48: 420-432. http://dx.doi.org/10.5465/AMJ.2005.17407908

WANG, P.; RODE, J.C. (2010). Transformational leadership and follower creativity: the moderating effects of identification with leader and organizational climate. Human relations, 63(8): 1105-1128. http://dx.doi.org/10.1177/0018726709354132

WEBER, M. (1968). On charisma and institution building. Chicago: University of Chicago Press. 
YAMMARINO, F.J.; SPANGLER, W.D.; BASS, B.M. (1993). Transformational leadership and performance: a longitudinal investigation. Leadership Quarterly, 4: 81-102. http://dx.doi.org/10.1016/1048-9843(93)90005-E

YUKL, G.A (1998). Leadership in organizations (4th ed.). Upper Saddle River, NJ: Prentice-Hall, Inc.

YUKL, G.A (1999). An evaluation of conceptual weaknesses in transformational and charismatic leadership theories. The Leadership Quarterly, 10: 285-305. http://dx.doi.org/10.1016/S10489843(99)00013-2

YUKL, G.A. (1981). Leadership in organizations. Englewood Cliffs, NJ: Prentice-Hall.

YUKL, G.A. (1989). Leadership in Organizations (2nd ed.). Englewood Cliffs, NJ: Prentice Hall.

Intangible Capital, 2014 (www.intangiblecapital.org) 